\title{
Demin D. INVESTIGATION OF STRUCTURAL CAST IRON HARDNESS FOR CASTINGS OF AUTOMOBILE INDUSTRY ON THE BASIS OF CONSTRUCTION AND ANALYSIS OF REGRESSION EOUATION IN THE FACTOR SPACE «CARBON (C) - CARBON EOUIVALENT ( $\left.\mathbf{C}_{\mathrm{eq}}\right) »$
}

Об'єктом дослідження є конструкиійний чавун з пластинчастим графітом, в якому вуглецевий еквівалент $\left(C_{\text {екв }}\right)$ знаходиться в діапазоні $(4,2-4,4) \%$, а вміст вуглецю $(C)$ в діапазоні $(3,42-3,57) \%$. Дослідження полягало в описі розподілу величини твердості конструкційного чавуну серійних плавок в факторному просторі $\mathrm{C}-\mathrm{C}_{\text {екв }}$ при фіксованих у вузьких інтервалах значеннях вмісту $\mathrm{Cr}-\mathrm{Ni}-\mathrm{Cu}-\mathrm{Ti}$ легуючого комплексу. Показано, що для отримання пращездатного аналітичного опису може бути використано поліноміальне рівняння регресії виду $H B=H B\left(C, C_{\text {екв}}\right)$. Показано, що така структура рівняння $і$ отримані методом найменших квадратів відповідні оцінки коефіиієнтів забезпечують 92 \% -ву точність прогнозу навіть при малій вибіриі даних.

На основі канонічного перетворення поверхні відгуку і їі, і гребневого аналізу встановлена принципова можливість задоволення різних вимог до твердості. Так, якщо в якості накладається обмеження вибрати діапазон галузі планування $C=(3,42-3,57) \%$ і $C_{\text {екв }}=(4,2-4,4) \%$, то можливе існування декількох субоптимальних рішень. Це відбувається в тому випадку, якщо завдання мінімізації твердості не ставиться i діапазон НВ=180-250 задовольняє вимогам до якості, що задані умовами виробництва. Якщо ж пріоритетом є мінімізачія твердості, то субоптимальне рімення одне $i$ знаходиться воно як точка перетину лінії обмеження $(r=1,414)$ і нижньої гребньовій лінії $y=y(r)$. На підставі цього зроблено висновок про багатоваріантність субоптимальних рімень в залежності від вимог виробництва. Побудована номограма, що дозволяє вибирати раціональним чином технологічні режими позапічної обробки в частині, що стосується коригування хімічного складу сплаву.

Ключові слова: твердість чавуну, конструкиійний чавун, хімічний склад чавуну, рівняння регресії, канонічне перетворення, гребеневий аналіз.

\section{Introduction}

In the technologies of foundry production, priority is given to the quality management of obtained castings. Taking into account the fact that the quality of castings is formed by two components of technological processes - the metallurgical component and the technology of the mold there are basically two main approaches to research. The first of them is based on a comprehensive study of the design and manufacture of casting technology, the second on the study of smelting and out-of-furnace processing [1-3]. Among the considered quality criteria, the surface cleanliness, the presence of surface defects, the correspondence of dimensional and geometric accuracy specified in the design documentation, mechanical and special properties can be distinguished. And if the first are formed by the technological components of the process - the mold technology, the latter is formed by the metallurgical component, which depends on the melting and out-of-furnace processing. It is the mechanical properties - the ultimate tensile strength and hardness - that are controlled by government standards. At the same time, it should be noted that when comparing samples of constructional cast iron with general machine-building design, preference should be given to those with a maximum tensile strength and a minimum hardness. With regard to hardness, it is necessary to take into account that the lower level of the hardness should provide the specified performance properties in case the surface is contacting. The upper level of hardness should ensure the possibility of high-quality machining and do not cause a reduction in the reliability of the metalworking tool. It is also important to take into account that sudden increase in hardness indicates changes in the microstructure and the formation of carbides. In particular, we can talk about the most dangerous for structural iron carbon carbide $\mathrm{Fe}_{3} \mathrm{C}$. Thus, hardness as a regulated quality indicator of structural iron is important from the technological point of view, and with information - as an indirect indicator, indicating undesirable changes in the microstructure. Therefore, the research areas devoted to the study of the effect of physical, chemical, technological and structural factors on the hardness of structural iron are relevant.

\section{The object of research and its technological audit}

The object of research is structural cast iron for commercial castings for automotive castings, in which the carbon 
equivalent $\left(C_{e q}\right)$ is in the range $(4.2-4.4) \%$, and the carbon content $(C)$ in the range $(3.42-3.57) \%$. Previous studies on the effect of carbon and carbon equivalent on the ultimate tensile strength [4] required additional hardness studies. This production need is caused by the importance of evaluating the effect of $C$ and $C_{e q}$ on hardness, in order to study the possibilities of its reduction for free surfaces of castings without adversely affecting the strength parameters. Such decrease in the hardness of structural iron within acceptable limits can also contribute to improvement of the machining processes for the surfaces. Finally, the availability of sound technological solutions, based on an adequate analytical description of the effect of $C$ and $C_{e q}$ on hardness, can help reduce costs in the smelting of structural cast iron. This is ensured by minimizing them on the basis of the choice of the optimum composition of the charge for the minimum cost.

From the point of view of theoretical results, it is of interest to investigate the joint effect of carbon and carbon equivalent on hardness as an indirect indicator for the subsequent study of the mechanisms of the formation of cast iron microstructure.

Technological audit was carried out in the foundry of JSC «Kremenchuk plant of road machines» (Kremenchuk, Ukraine). The technological audit was aimed at revealing real quantitative characteristics of hardness (HB) in the specified range of $C-C_{e q}$ at realization of the basic technological process of induction melting of synthetic cast iron C420 GOST1412-85. The melting was carried out in an induction crucible furnace with an acid lining ИСТ1/0.8-М5. As a modifier, ferrosilicon FeSi75 was used. Detailed technological process regimes are described in [4].

In accordance with the technological instructions in force at the enterprise, samples were taken for chemical analysis, and wedge samples were cast to determine the hardness of cast iron in accordance with GOST 1412-85.

\section{The aim and objectives of research}

The aim of research is description of the hardness distribution of structural cast iron for series castings for automotive castings in the $C-C_{e q}$ factor space in the ranges $C=(3.42-3.57) \%$ and $C_{e q}=(4.2-4.4) \%$, for fixed in narrow intervals, the values of the $\mathrm{Cr}-\mathrm{Ni}-\mathrm{Cu}-\mathrm{Ti}$ content of the alloying complex. This would give an opportunity to choose the optimal values for $C$ and $C_{e q}$ for the selected criteria for the subsequent evaluation of the possibility of minimizing costs in the smelting of cast iron.

To achieve this aim, it is necessary to solve the following tasks.

1. Construction of a workable analytical description of the influence of the selected input variables on cast iron hardness.

2. Investigation of the response surface for the presence of optimal or suboptimal values of input variables.

\section{Research of existing solutions of the problem}

Hardness, as one of the quality indicators of structural iron, depends on a variety of technological factors, but on the other hand, its magnitude is related to macro- and microstructure. Theoretically, any impact in the technological process can affect the change in hardness, precisely as one of the quality indicators. Therefore, researchers, as a rule, approach the solution of problems in a complex manner. Thus, a method for estimating microstructural inhomogeneities: graphite, foundry defects, and the structure of a metal matrix were proposed in [5]. The latter, as is known, is the determining factor for the formation of hardness of structural cast iron. The proposed method allows, in the opinion of the authors, to predict the estimation of the output characteristic on the basis of information on microstructural inhomogeneities and loading conditions.

The studies described in [6] allowed to establish the qualitative influence of the new modifier containing $\mathrm{SiC}$, in combination with ferrosilicon FeSi75, on the morphology of graphite, the matrix structure and the mechanical properties of cast iron. It has been established that it is possible to form a large number of microzones with a high content of carbon and a silicon concentration that promote a favorable course of the graphitization process. However, the assessment was carried out only at a qualitative level. The influence of the modifier composition in the mold on the microstructure and fatigue strength of castings made from cast iron EN GJS 700-2 is described in [7]. In this paper, the authors talk about the possibility of managing properties through effective modification. In this case, efficiency is considered in the sense of a specified targeted effect on the microstructure of the alloy. However, the problem is investigated primarily on the basis of a material science, rather than a technological approach.

In a number of works, for example, [8,9], it was noted that regression analysis or modified Griffiths and HallPetch equations can be used to study the formation of a metal matrix. Here it should be noted once again that if the strength of cast iron depends mainly on the amount, shape, size and distribution of graphite, then the hardness is determined mainly by the metal matrix.

The influence of the alloying parameters, together with the regulation of the $\mathrm{C} / \mathrm{Si}$ ratio in cast iron, on the microstructure and the mechanical properties of cast iron, is described in [10]. In this work, it is established that the output characteristics of the cast iron modifier in combination with antimony ( $\mathrm{Sb}$ ) influence the data. However, the results described in this paper refer to high-strength cast iron and the possibility of spreading the findings in it to cast iron with plate graphite requires additional studies. The problem of globular graphite formation during the modification of cast iron by magnesium is given attention in [11], and the choice of the modifier type and the development of modifying technology as technological factors for controlling mechanical properties are discussed in [12-14]. Among the most highly developed modifiers, for example, the Superseed ${ }^{\circledR}$ Extra Inoculant [12], Reseed ${ }^{\circledR}$ Inoculant [13] and $\mathrm{SMZ}^{\circledR}$ Inoculant [14] modifiers can be noted. The Superseed ${ }^{\circledR}$ Extra Inoculant modifier minimizes bleaching in cast iron castings, promotes the formation of evenly distributed graphite, neutralizes the harmful effects of nitrogen and promotes the formation of small graphite inclusions, reducing the graphite chipping during machining. This effect of the modifier is explained by the authors in the presence of zirconium and strontium in its composition, which improve the nucleation with a minimum degree of supercooling and reduce the risk of formation of supercooled graphite and ferrite. The Reseed ${ }^{\circledR}$ Inoculant modifier is designed for high-strength 
and gray cast iron with low sulfur content and contributes, in particular, to the formation of globular graphite with a good degree of globularity in the thick sections of castings from high-strength cast iron. Also, this modifier helps to prevent the formation of micro-shrinkage porosity in the castings. This effect is ensured by the presence in the modifier of a balanced number of active elements calcium and cerium. Obviously, due to these effects, one should expect an increase in the cast iron hardness. The $\mathrm{SMZ}^{\circledR}$ Inoculant modifier can be used for graphitizing modification of gray cast iron and vermicular graphite cast iron and is suitable for late modification in a metal stream (MSI process). This ensures stabilization of deviations in chemical composition and regulation of nitrogen content in cast iron. Such effect, as the authors of [12] note, can be explained by a carefully balanced amount of calcium and aluminum, which ensures maximum control over bleaching. Despite the qualitative assessment of the expected effects of the modification, the lack of quantitative estimates, which can only be made on the basis of an analytical description, does not allow making sound technological decisions. In particular, we can talk about the selection of the chemical composition that provides the specified properties, and allows the possibility of optimizing the charge by the criterion of minimum costs. Certain exceptions in considering the problem from this point of view have the works $[15,16]$, in which the accent is made precisely on the methods of quantitative evaluation. The authors of these works have investigated the use of methods for constructing «composition-properties» models under conditions of uncertainty, with hardness chosen as the output variable.

The described work allows to conclude that there are no ready solutions for the reasonable choice of the composition of cast iron from the point of view of ensuring a given hardness. As for the questions of the effect of the chemical composition of cast iron in a specific range of variation of the input $C-C_{E Q}$ on the hardness of structural iron, the corresponding work has not been found. Therefore, to solve the emerging practical issues on the choice of the chemical composition of cast iron, which provides the given values of its hardness and which allows further minimizing the cost of its production, special studies are necessary.

\section{Methods of research}

According to the results of industrial tests, described in detail in [4], a sample of input and output variables is formed. This sample includes the results of 200 serial meltings, of which the data are selected that fell within the range $C=(3.42-3.57) \%$ and $C_{e q}=(4.2-4.4) \%$. The data are preliminarily filtered and normalized by a standard procedure [4], the input variable «carbon content $(C) »$ is denoted by $x_{1}$, the input variable «carbon equivalent $\left(C_{e q}\right)$ » is denoted by $x_{2}$. Fig. 1 shows the hardness values of 12 samples selected for further study.

The possibility of constructing an efficient mathematical model in the form of a regression equation is investigated:

$$
y_{i}=a_{0}+a_{1} x_{1}+a_{2} x_{2}+a_{3}\left(x_{1}\right)^{2}+a_{4}\left(x_{2}\right)^{2}+a_{5} x_{1} x_{2}
$$

where $a_{i}$ - the estimated coefficients.

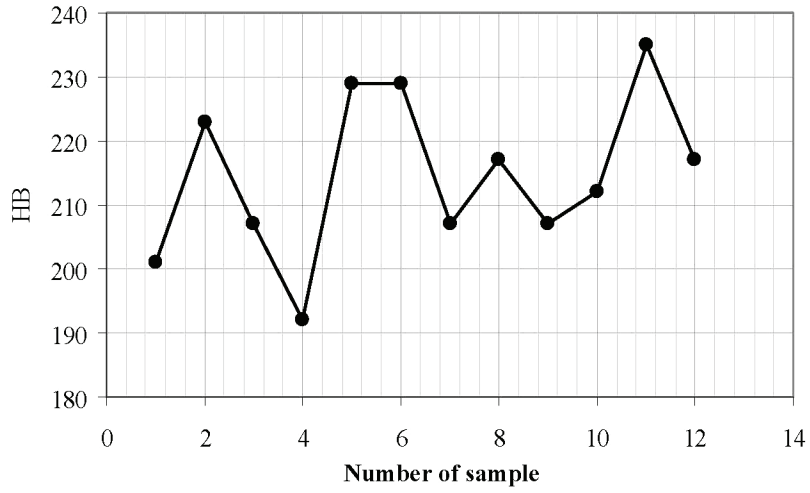

Fig. 1. Hardness values of 12 samples selected for further investigation

To estimate the vectors:

$$
\mathrm{A}=\left(\begin{array}{l}
a_{0} \\
a_{1} \\
a_{2} \\
a_{3}
\end{array}\right) \text { and } \mathrm{A}=\left(\begin{array}{c}
a_{0} \\
a_{1} \\
a_{2} \\
a_{3} \\
a_{4} \\
a_{5}
\end{array}\right),
$$

the least squares (OLS) method is used:

$$
A=\left(F^{\prime} F\right)^{-1} F^{\prime} Y=C F^{\prime} Y
$$

minimizing the least-squares functional of the form:

$$
J=(F A-Y)^{T}(F A-Y),
$$

where $F$ - the matrix of the experimental design, which has the form:

$$
F=\begin{array}{cccccc}
1 & x_{11} & x_{12} & x_{11} x_{12} & x_{11}^{2} & x_{12}^{2} ; \\
1 & x_{21} & x_{22} & x_{21} x_{22} & x_{21}^{2} & x_{22}^{2} ; \\
\cdot & \cdot & . & . & . & \cdot
\end{array} ;
$$

$$
\mathrm{Y}=\left(\begin{array}{l}
y_{1} \\
y_{2} \\
\cdot \\
y_{n}
\end{array}\right)
$$

- matrix of experimental hardness values.

\section{Research results}

Using the OLS, the values of the coefficients of the regression equations of the form (1) are calculated from (2):

$$
A=\left(\begin{array}{l}
216.934 \\
-11.7595 \\
1.057318 \\
2.341327 \\
4.389574 \\
-37.0113
\end{array}\right)
$$


Considering the fact that the coefficients of the regression equations are estimated on the basis of a passive experiment that does not allow parallel measurements of the output variable at each point of the plan, the possibility of testing the homogeneity of the experimental plan is not available. The adequacy of the model, based on Fisher's F-test, or testing the hypothesis that the variance of experimental errors is equal, and the model's inadequacy, is not therefore possible. Therefore, the potential performance of the model us evaluated on the basis of checking the number of experimental points that fell within a given confidence interval (Fig. 2).

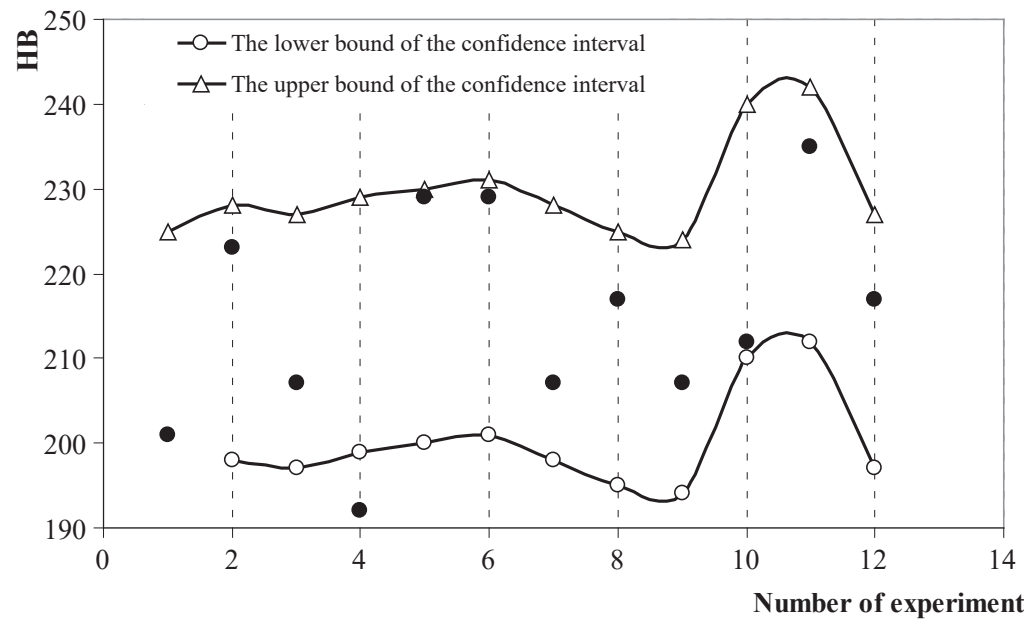

Fig. 2. Results of testing the model's performance on the basis of the polynomial regression equation
As a result of the transfer and rotation of the axes and the transition from the coordinate system $\left(x_{1} ; x_{2}\right)$ to the coordinate system $\left(\xi_{1} ; \xi_{2}\right)$, the initial equation of the response surface is transformed to:

$$
y(x)=a_{0}+2 a^{\prime} x+x^{\prime} A x,
$$

the canonical form $y-y^{*}=\lambda_{1} \xi_{1}^{2}+\lambda_{2} \xi_{2}^{2}+\ldots+\lambda_{n} \xi_{n}^{2}$ :

$$
x=x^{*}+\mathrm{B} \xi,
$$

where $\mathrm{B}$ - the rotation matrix, $B^{\prime} B=I$, and the difference between the values of the output variable at an arbitrary and stationary point is described by the equation:

$$
y(\xi)-y^{*}=\xi^{\prime} L \xi
$$

The following values are obtained by the realization of the procedure $1-4: \lambda_{1}=-15.1685$, $\lambda_{2}=21.89937$. This means that the equation describing the response surface in the canonical form has the form:

$$
y-y^{*}=-15.1685 \xi_{1}^{2}+21.89937 \xi_{2}^{2}
$$

Since the ratio of the eigenvalues in magnitude and sign determines the form of the response surface, and:

$$
\left|\lambda_{1}\right| \neq\left|\lambda_{2}\right|, \lambda_{1}<0, \lambda_{2}>0,
$$

From Fig. 2 it follows that 11 test points (92\%) fell into the confidence interval. Therefore, there is reason to believe that the regression equation of the form (1) is operable for further analysis.

Since the most interesting is the identification of stationary points and the description of the response surface in their vicinity, the canonical transformation of the response surface is performed, similarly to the procedure described in [4]:

1. Determination of the coordinates of the stationary point $x^{*}$ by solving a system of linear equations:

$$
\left(\begin{array}{ccc}
a_{11} & \ldots & a_{1 n} \\
\vdots & \ddots & \vdots \\
a_{m 1} & \cdots & a_{m n}
\end{array}\right)\left(\begin{array}{l}
x_{1}^{*} \\
\cdot \\
x_{n}^{*}
\end{array}\right)=-\left(\begin{array}{l}
a_{1} \\
\cdot \\
a_{n}
\end{array}\right) \text {. }
$$

2. Calculation of the target value at a stationary point:

$$
y^{*}=a_{0}+2 a^{\prime} x^{*}+x^{* \prime} A x^{*}
$$

3. Definition of $n$ eigenvalues $\lambda_{1}, \lambda_{2}, \ldots, \lambda_{n}$ :

$$
\left|\begin{array}{cccc}
a_{11}-\lambda & a_{12} & \ldots & a_{1 n} \\
a_{21} & a_{22}-\lambda & \ldots & a_{2 n} \\
\cdot & \cdot & . & \cdot \\
a_{n 1} & a_{n 2} & \ldots & a_{n n}-\lambda
\end{array}\right|=(-\lambda)^{n}+P_{1} \lambda^{n-1}+\ldots P_{n}=0
$$

4. Description of the equation of the response surface in the canonical form:

$$
y-y^{*}=\lambda_{1} \xi_{1}^{2}+\lambda_{2} \xi_{2}^{2}+\ldots+\lambda_{n} \xi_{n}^{2}
$$

the response surface, just as in the case of a tensile strength test [4], is a hyperbolic parabaloid. However, the position of the saddle point in it is not so pronounced (Fig. 3).

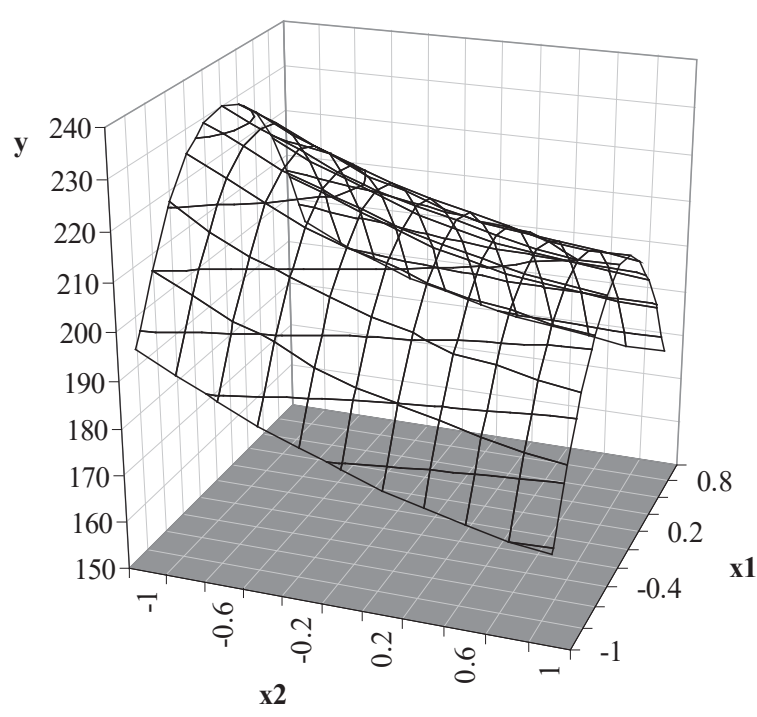

Fig. 3. The response surface, which describes the distribution of hardness values of structural iron in the factor space $C-\Gamma_{e q}$ (input variables are given in the normalized form)

Fig. 4 is a top view of the response surface, from which it can be seen that with the increase in the carbon equivalent, the hardness of the cast iron is reduced. The effect of the carbon content on hardness is more complex - it is described by a parabolic dependence. 
This means that the maximum hardness is reached at about the average level of carbon content (3.495\%). Before this value, the hardness increases with increasing carbon content, and then decreases.

In other words, from the point of view of using carbon as a factor in reducing the hardness of cast iron, its allowable range is limited to an interval (3.42-3.495) \%. A more significant factor from this point of view is the carbon equivalent, which needs to be increased. This means that in order to reduce the hardness value it is necessary to increase the width of the $C-C_{e q}$ interval in the $\mathrm{Fe}-\mathrm{C}$ state diagram.

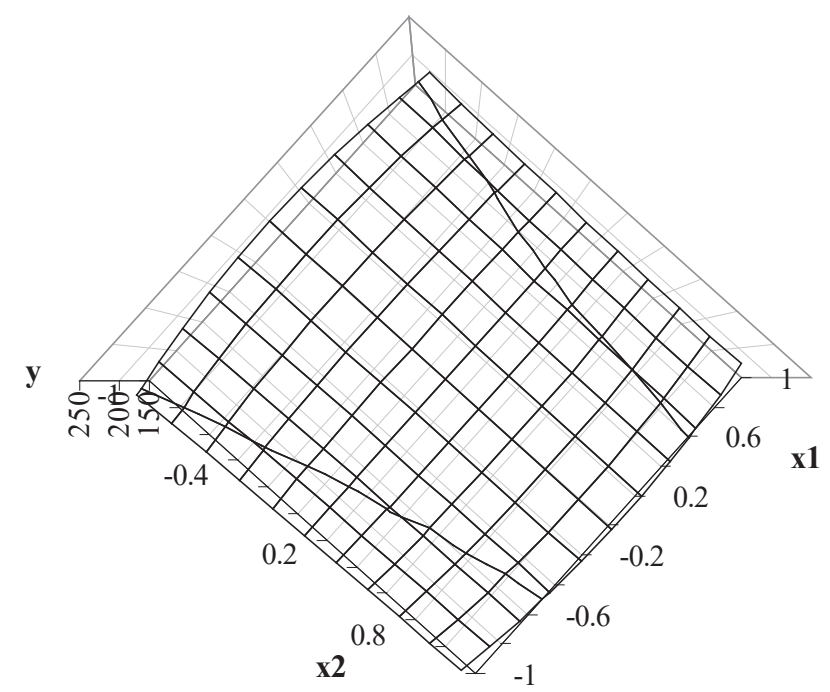

Fig. 4. The response surface $H B=H B\left(C, \Gamma_{e q}\right)$, top view, (the input variables are given in the normalized form)

To find suboptimal points, it is advisable to use the ridge analysis of the received response surface [17]. To do this, it is necessary to obtain a parametric description of the type:

$$
\left\{\begin{array}{l}
x^{*}(\lambda)=(\lambda I-A)^{-1} a, \\
r(\lambda)=\sqrt{x^{* \prime} x^{*}}, \\
y^{*}(\lambda)=a_{0}+2 a^{\prime} x^{*}+x^{* \prime} A x^{*},
\end{array}\right.
$$

where $a_{0}, a, A$ - estimates of the coefficients in the regression equation (1); $x_{i}^{*}=\frac{a_{i}}{2 \lambda}-$ suboptimal values of input variables; $r=\sqrt{r^{2}}, r^{2}=\sum_{i=1}^{n}\left(\frac{a_{i}}{2 \lambda}\right)^{2}-$ restrictions imposed on the values of input variables in the factor space $\left(C\right.$ and $\left.C_{e q}\right) ; y^{*}=a_{0}+\sum_{i=1}^{n} \frac{a_{i}^{2}}{2 \lambda}-$ suboptimal values of the output variable (HB).

Fig. 5-7 shows a graphical solution to the problem of ridge analysis of the obtained response surface $H B=H B\left(C, C_{e q}\right)$ (Fig. 3) analytically described by the regression equation of the form (1). If the range of the planning region is chosen as the imposed constraint, $C=(3.42-3.57) \%$ and $C_{e q}=(4.2-4.4) \%$ (in the normalized form $\left.[-1 ; 1]\right)$, which corresponds to the value of $r=\sqrt{2}=1.414$. There may be several suboptimal solutions. They are defined as the intersection points of the ridges and the constraints $r=1.414$. In this case, the tasks of minimizing hardness are not set and the range $H B=180-250$ satisfies the quality requirements specified by the production conditions. If the priority is to minimize hardness, then the suboptimal solution is found as the point of intersection of the restriction $r=1.414$ and the lower branch of the ridge line II-III. Consequently, the resulting results in the form of Fig. 7 allow to draw a number of important conclusions from the practical point of view concerning the satisfaction of different requirements for hardness. This indicates the multivariance of the obtained solutions, the choice of the most preferable of which is determined by the requirements of the production conditions.

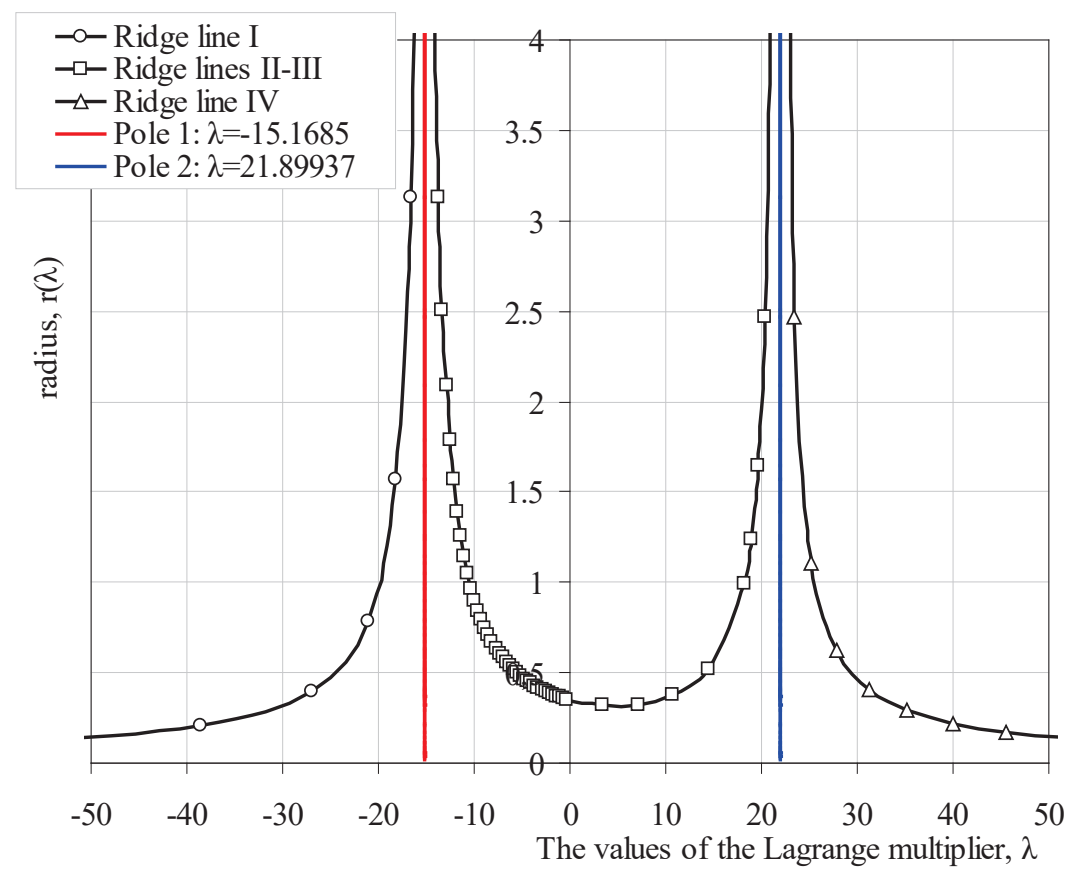

Fig. 5. Dependence $r=r(\lambda)$ 


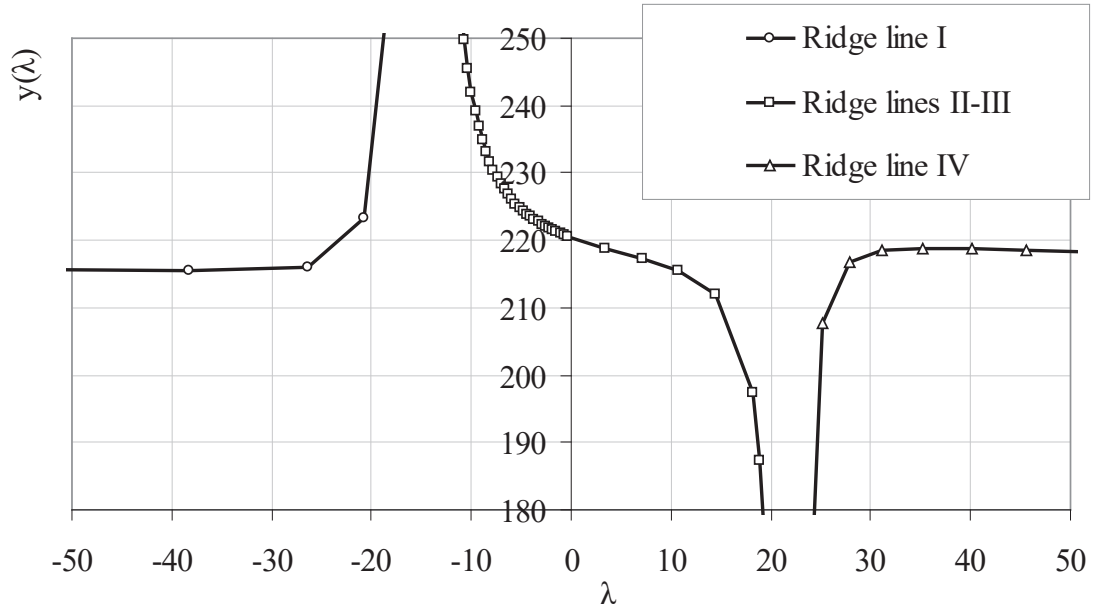

Fig. 6. Dependence $y=y(\lambda)$

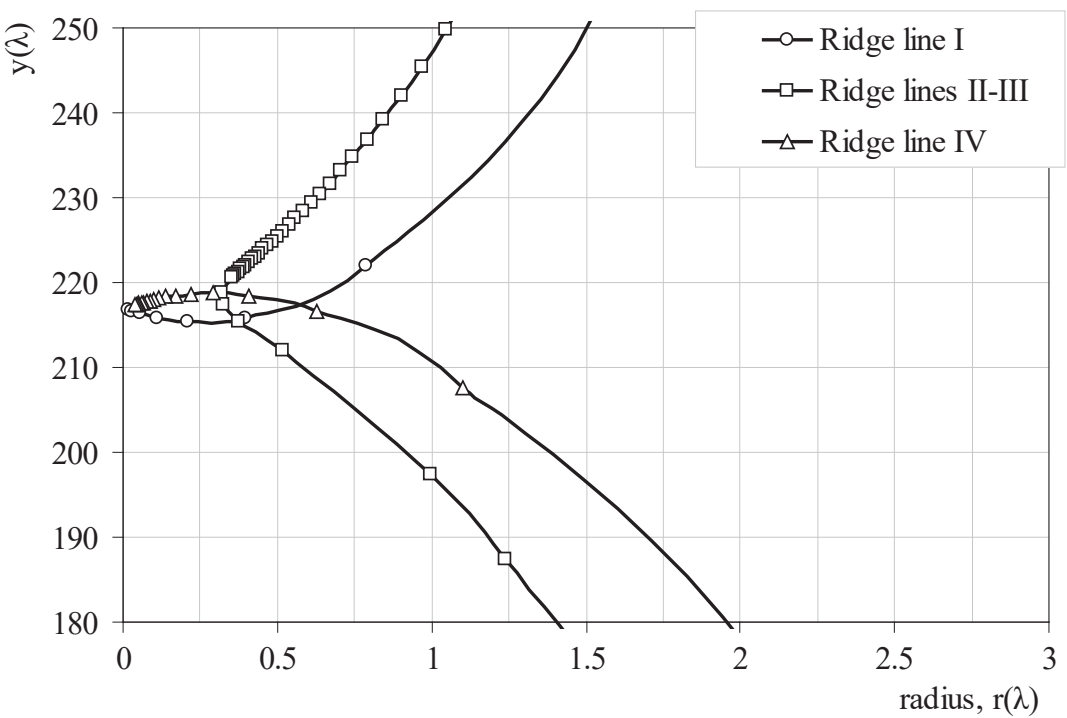

Fig. 7. Dependence $y=y(r)$

Obviously, there are many suboptimal solutions given by the first equation of system (8). For the case when the requirements $H B=180-250$ are sufficient, such solutions are shown in Fig. 8.

From a practical point of view, the transformation of the solutions obtained in a normalized form to a natural form is of special interest - obtained description is a nomogram. The nomogram, as is known, is a convenient tool in the hands of a technologist [18-20], and allows choosing rational modes of the technological process. Fig. 9 shows such nomogram for the investigated range of values of input variables.

As follows from the above description, in order to select the necessary correction value for the carbon or carbon equivalent, it is possible to estimate the distance between the point of the factor space corresponding to the actual values of $C$ and $C_{e q}$ and the nearest of the two curves.

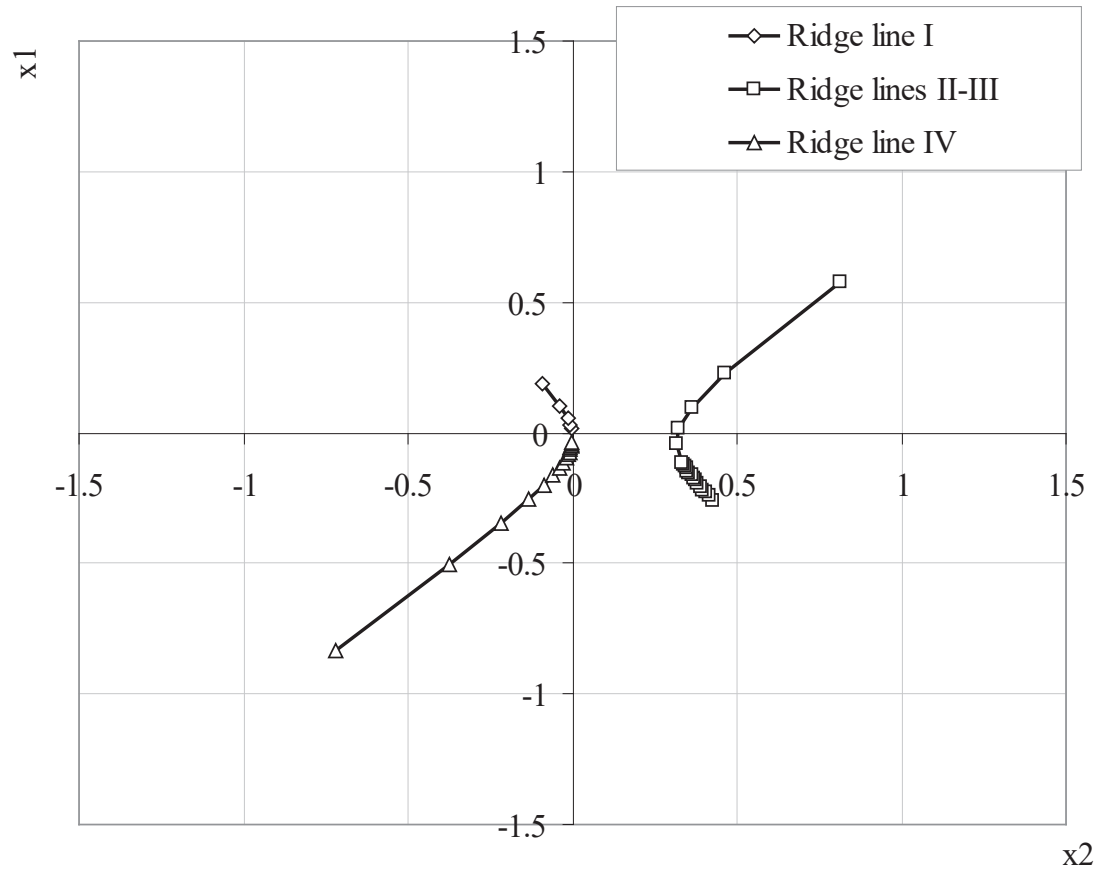

Fig. 8. Set of suboptimal solutions to determine the values of input variables that satisfy the requirements $H B=180-250$ (the input variables are given in the normalized form) 


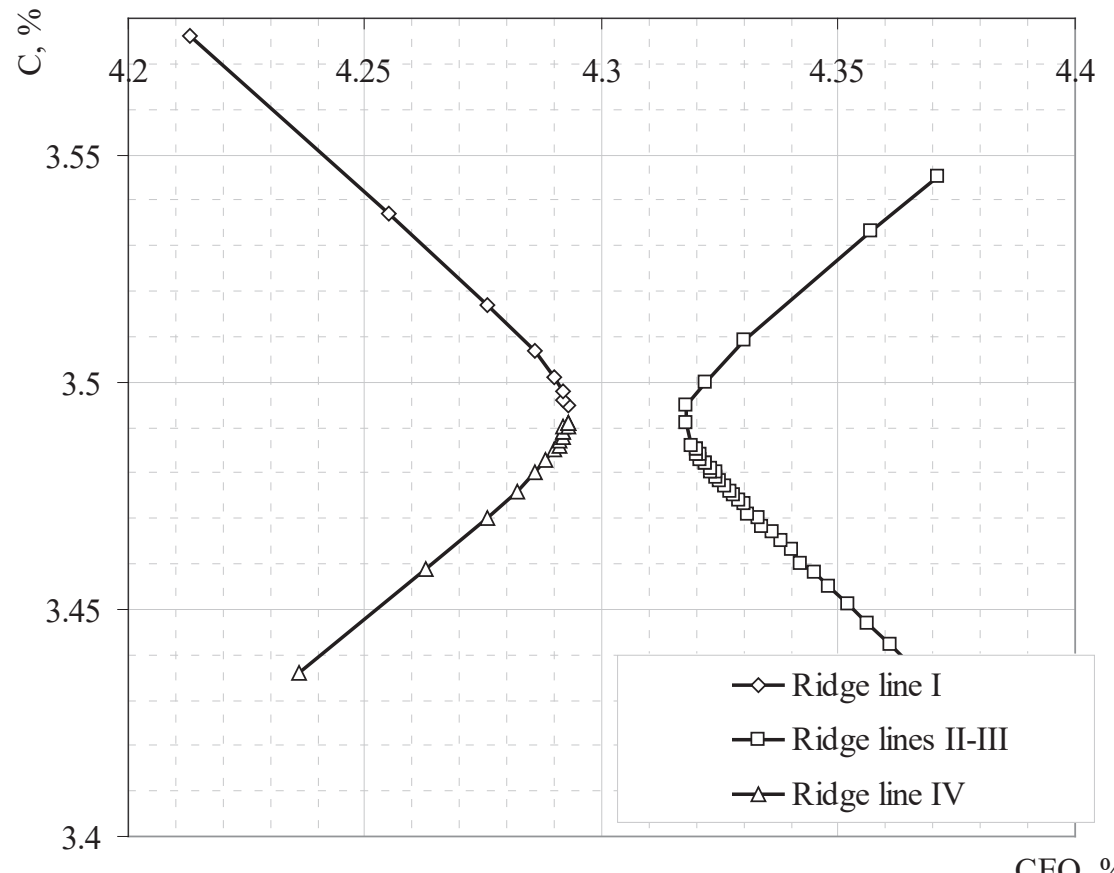

CEQ, \%

Fig. 9. Nomogram describing the set of suboptimal solutions for the investigated range of values of input variables satisfying the requirements of $H B=180-250$

Obviously, the best choice will be the one providing the minimum consumption of corrective additives, that is, one for which the distance from the current point (corresponding to the actual values of $C$ and $C_{e q}$ ) to the corresponding curve will be minimal.

\section{SWOT analysis of research results}

Strengths. Among the strengths of this research, it is necessary to note the possibility of using the resulting regression equation to solve two key problems:

- predicting the hardness by the actual chemical composition, obtained during the melting process;

- selection of the composition providing a given level of hardness. In the first case, it becomes possible to reduce the number of laboratory hardness tests by reducing the corresponding costs. In the second case, the prospect of minimizing the cost of the burden opens, that is, reducing the cost of 1 ton of good casting. It should also be noted that the possibility of an indirect evaluation of the appearance of undesirable carbides in the microstructure, in particular cementite, is possible. This can contribute to the selection of more rational solutions with regard to the technological regimes of secondary treatment. Finally, a targeted choice of chemical composition, which provides minimum, but acceptable from the standpoint of strength, hardness of structural iron should contribute to improving the reliability of the cutting tool.

Weaknesses. The weaknesses of this research are related to the fact that the regression equation is built on the basis of an arbitrary area of experiment planning. This means that the obtained estimates of the coefficients are far from optimal and there is a principal possibility of increasing the accuracy. This is possible, for example, by optimizing the experimental design. However, this desire to improve quality will require the need for additional fusions, which is associated with significant additional costs.

Opportunities. Additional opportunities for using the above results in industrial conditions are related to the optimization of the chemical composition of cast iron or the optimization of the charge composition. In the latter case, the initial data can be obtained suboptimal solutions. Additional opportunities are also opened during the off-furnace treatment - thanks to the use of obtained nomograms, the rational selection of corrective additives is simplified. In this case, there is a principal possibility to minimize costs precisely at the expense of the most acceptable option.

Threats. The obvious risks when using the results are due to the fact that consumers prefer to purchase castings from high-strength cast iron with nodular graphite or high-quality gray cast iron with vermicular graphite. This is completely justified, since the mechanical or special properties of such cast irons are much higher. From the point of view of the manufacturer of cast iron for castings, if the operating conditions of cast iron parts are non-rigid, typical, there is no need to spend extra money in pursuit of increasing mechanical properties. And if the manufacturer's costs are one of the criteria for minimization, then they are not interested in the consumer. From the point of view of using the obtained solutions in production, there is a management risk - changing the composition of the charge requires a revision of the consumption rates, and possibly suppliers of charge materials. This, in turn, requires the presence of progressive management and especially the corresponding level of top managers of production.

\section{Conclusions}

1. It is shown that a polynomial regression equation can be used to obtain a workable analytical description of the effect of carbon $(C)$ and the carbon equivalent $\left(C_{e q}\right)$ 
on the hardness value. The solutions obtained in the construction of the regression equation of the form $H B=$ $=H B\left(C, C_{e q}\right)$ refer to the range of values of the input variables $C=(3.42-3.57) \%$ and $C_{e q}=(4.2-4.4) \%$. This structure of the equation and the corresponding estimates of the coefficients obtained by the least squares method ensure high accuracy of the forecast. Even with a small sample of data, this accuracy is $92 \%$.

2. On the basis of the canonical transformation of the received response surface, the presence of a saddle point is revealed, which, however, is not as pronounced as for a response surface that describes the magnitude of the tensile strength in the same range of input variables. The ridge analysis of the described response surface shows that there is a principal possibility of satisfying different requirements for hardness. So, if the range of the planning area $C=(3.42-3.57) \%$ and $C_{e q}=(4.2-4.4) \%$ is chosen as the imposed constraint, then several suboptimal solutions are possible. This is the case if the task of minimizing hardness is not set and the range $H B=180-250$ satisfies the quality requirements specified by the production conditions. If the priority is hardness minimization, then the suboptimal solution is one. Thus, there are many suboptimal decisions, depending on the requirements of production. It is shown that such solutions, in fact, are a nomogram that allows to select in a rational way the technological regimes of out-of-furnace processing in the part concerning the correction of the chemical composition of the alloy.

\section{References}

1. Lysenko T. V., Stanovskii A. L. Adaptivnoe avtomatizirovannoe sinhroniziruiushchee proektirovanie sistemy «otlivka-peschanaia forma» NTI // Zbirnyk naukovykh prats Odeskoi natsionalnoi morskoi akademii. 2008. Vol. 13. P. 82-88.

2. Hrychikov V. E., Koteshov N. P. Vliianie kombinirovannoi kokil'no-peschanoi liteinoi formy na zatverdevanie i formirovanie makrostruktury $\mathrm{v}$ krupnih otlivkah iz vysokoprochnogo chuguna // Liteinoe proizvodstvo. 1994. No. 12. P. 12.

3. Povyshenie germetichnosti otlivok iz serogo chuguna / Ivanova L. A. et al. // Puti povysheniia kachestva i ekonomichnosti liteinyh protsessov. Odessa, 1995. P. 11-13.

4. Demin, D. Strength analysis of lamellar graphite cast iron in the «carbon $(C)$ - carbon equivalent $\left(C_{e q}\right)$ » factor space in the range of $C=(3.425-3.563) \%$ and $C_{e q}=(4.214-4.372) \% / /$ Technology audit and production reserves. 2017. Vol. 1, No. 1 (33). P. 24-32. doi: http://doi.org/10.15587/2312-8372.2017.93178

5. Endo M., Yanase K. Effects of small defects, matrix structures and loading conditions on the fatigue strength of ductile cast irons // Theoretical and Applied Fracture Mechanics. 2014. Vol. 69. P. 34-43. doi: http://doi.org/10.1016/j.tafmec.2013.12.005

6. Test research on the effects of mechanochemically activated iron tailings on the compressive strength of concrete / Cheng Y. et al. // Construction and Building Materials. 2016.
Vol. 118. P. 164-170. doi: http://doi.org/10.1016/j.conbuildmat.2016.05.020

7. Effect of in-mould inoculant composition on microstructure and fatigue behaviour of heavy section ductile iron castings / Borsato T. et al. // Procedia Structural Integrity. 2016. Vol. 2. P. 3150-3157. doi: http://doi.org/10.1016/j.prostr.2016.06.393

8. Fourlakidis V., Dioszegi A. A generic model to predict the ultimate tensile strength in pearlitic lamellar graphite iron // Materials Science and Engineering: A. 2014. Vol. 618. P. 161-167. doi: http://doi.org/10.1016/j.msea.2014.08.061

9. Manasbekov N. M. Vliianiia soderzhaniia sery na svoistva sinteticheskogo chuguna // Molodiozh' i nauka: Sbornik materialov VIII Vserossiiskoi nauchno-tehnicheskoi konferentsii studentov, aspirantov i molodyh uchionyh, posviashchennoi 155-letiiu so dnia rozhdeniia K. E. Tsiolkovskogo. Krasnoyarsk: Siberian Federal University, 2012. URL: http://conf.sfu-kras.ru/sites/ mn2012/section37.html

10. Chemical Compositions, Microstructure and Mechanical Properties of Roll Core used Ductile Iron in Centrifugal Casting Composite Rolls / Bai Y. et al. // Journal of Materials Science \& Technology. 2012. Vol. 28, No. 9. P. 853-858. doi: http:// doi.org/10.1016/s1005-0302(12)60142-x

11. Hrychikov V. E. K voprosu obrazovaniia sharovidnogo grafita pri modifitsirovanii chuguna magniem // Liteinoe proizvodstvo. 1997. No. 2. P. 5-7.

12. Elkem ASA Research. Modifikator Superseed®Extra Inoculant // ITB «Litio Ukrainy». 2003. No. 12 (40).

13. Elkem ASA Research. Modifikator Reseed ${ }^{\circledR}$ Inoculant // ITB «Litio Ukrainy». 2004. No. 7 (47).

14. Elkem ASA Research. Modifikator SMZ ${ }^{\circledR}$ Inoculant // ITB «Litio Ukrainy». 2004. No. 5 (45).

15. Bondarchuk A. A., Matveev M. G., Polianskii Yu. A. Modeli upravleniia tverdost'iu metalla v usloviiah stohasticheskoi i nechetkoi neopredelennosti // Sistemy upravleniia i informatsionnye tehnologii. 2007. No. 4.1. P. 124-128.

16. Bondarchuk A. A., Matveev M. G. Modeli vybora sostava $\mathrm{v}$ sisteme «sostav-svoistvo»// Materialy XX mezhdunarodnoi nauchnoi konferentsii «Matematicheskie metody v tehnike i tehnologiiah». Yaroslavl: Yaroslavl State Technical University, 2007. Vol. 2. P. 139-140.

17. Demin D. Synthesis of optimal control of technological processes based on a multialternative parametric description of the final state // Eastern-European Journal of Enterprise Technologies. 2017. Vol. 3, No. 4 (87). P. 51-63. doi: http:// doi.org/10.15587/1729-4061.2017.105294

18. Demin D. A., Pelikh V. F., Ponomarenko O. I. Optimization of the method of adjustment of chemical composition of flake graphite iron // Litejnoe Proizvodstvo. 1995. No. 7-8. P. 42-43.

19. Demin D. A., Pelikh V. F., Ponomarenko O. I. Complex alloying of grey cast iron // Litejnoe Proizvodstvo. 1998. No. 10. P. 18-19.

20. Modeling of the case depth and surface hardness of steel during ion nitriding / Mohanad M. K. et al. // Eastern-European Journal of Enterprise Technologies. 2016. Vol. 2, No. 5 (80). P. 45-49. doi: http://doi.org/10.15587/1729-4061.2016.65454

Demin Dmitriy, Doctor of Technical Sciences, Professor, Department of Foundry Production, National Technical University «Kharkiv Polytechnic Institute», Ukraine, e-mail: litvo11@kpi.kharkov.ua, ORCID: http://orcid.org/0000-0002-7946-3651 